\title{
CHINA, SINGAPORE AND KAZAKHSTAN: EXPERIENCE OF INTERNATIONAL TECHNOLOGICAL COOPERATION
}

\begin{abstract}
In modern conditions, the role of international industrial cooperation is increasing. Global industrial cooperation goes beyond normal interstate trade, direct cooperative link, and occupational production, foreign investment cooperation, and joint scientific and technical activities. International technological exchange, which serves as the dissemination of scientific and technological progress, also affects the effectiveness of the entire cycle of work, from development to commercial application. The forms of technology swapping are determined by the characteristics of the transferred technology and the characteristics of the subjects of the transfer process. The recipient of a technology or technologically intensive product gets the opportunity to assimilate most of the partner's scientific and technological experience. The article researches certain aspects of the technological development of Asian countries such as Singapore and China, whose experience in the area of successful international technological exchange is interesting to Kazakhstan and other countries that seek to actively integrate into global technological processes. The article assesses the existing systems for supporting innovations and stimulating high-tech industries in Kazakhstan. The article also provides an expert opinion of a foreign expert, Deputy Director of the Singapore organization the Action Community for Entrepreneurship, Brian Patrick Tan, as well as representatives of the venture Fund "Qaz Tech Venture" on the potential of integrating Kazakhstan into the international scientific and technical space.
\end{abstract}

Key words: technological exchange, licensing, scientific and technical cooperation, intellectual property, potential, integration, high-tech industries.

Recently, an alternative channel for industrial technology transfer, such as scientific and technical cooperation, has become increasingly popular. For this type of interethnic technology transfer, there is no established contractual form yet. The distinctive feature of such scientific and technical cooperation is that it mainly covers the field of applied research, which is closely related to the commercial implementation of the results of scientific research.

An example of scientific and technical collaboration is the Singapore and Japan's project on cooperation in the sphere of science and technology. On April 16, 2019, in Tokyo was held the first meeting of the Joint Committee of the two. Within the frame of the project, there is scientific and technical exchange, coordination of groundbreaking policies of countries, connection in the field of biomedical Sciences, information and communication technologies, space and the Arctic, joint fundamental and applied research, academic interchange, and more [1].

The experience of China is fascinating: China has achieved an unbelievable research and technological breakthrough in a short period. China has gained access to advanced technologies through openness and foreign investment, and the country has become a global manufacturing center. Since the late 1990s, it has moved from purchasing complete equipment to purchasing key equipment and non-materialized tech (patents, licenses, etc.).

Experts note that over $70 \%$ of technology purchases and $90 \%$ of industrial documentation and "know-how" account for Japan, the US and the EU. Japan accounts for up to half of the purchases of machinery and equipment. The Chinese practice of technology transfer is simple: the idea is American, the grinding is Japanese, the commercialization is Taiwanese, and the production is Chinese. Chinese 
enterprises began to move from technological dependence on their" intellectual partners "(at the first stage, almost all enterprises capable of producing high-complexity integrated circuits were registered with foreign capital) to their own production of modern microprocessor chips, when started to work under the"import-assimilation-innovation" scheme. This provided China with a leading position in the global digital equipment markets: basic (element base), primary (computers, mobile phones and communication equipment), secondary (CNC machines, military applications). Of course, the intellectual resources of its Asian partners helped China in this, especially Taiwan, which is the world's third producer of integrated circuits. [2, p. 158, 159].

During our disquisition, we interviewed a foreign expert, Deputy Director of the Singapore organization the Action Community for Entrepreneurship (ACE), Brian Patrick tan. The experience of this organization is interesting and useful for Kazakhstan. ACE is a national private organization that provides an interconnected ecosystem for innovation, startups, businesses, and talent. Led by the private sector, it aims to create a dynamic and efficient ecosystem of startups from Singapore. ACE was launched in 2003 by the Ministry of trade and industry and reorganized as a private enterprise in 2014. The government under the patronage of senior state Minister of trade and industry Ko Po Kun supports ACE. ACE plays a key role in providing the business community with strategic support to develop, scale startups, and create champion businesses [3]. ACE focuses on three strategic areas: access center for connected ecosystems; opportunities to expand the company's activities; accelerated promotion of joint innovation.

Brian Patrick Tan pointed out that research and improvement funding, venture capital resources, and technology testing markets can be barriers to technological growth. The fact is that during the evolving an investment strategy, venture assets, in order to maximize the return on their investments, rely on companies that have market leadership. This leads to limited access for technology companies at the early stages of the technology lifecycle to venture capital investments. Despite the great potential of such projects, as a result, this leads to the monopolization of the market by several major players.

Kazakhstan's practice of participating in the international scientific and technical partnership also has its own peculiarities. Kazakhstan uses a program-oriented approach to solve the problem of improving national competitiveness, which provides for effective interaction of scientific organizations and businesses in the innovation area through the implementation of shared technological programs. Such programs improve promising technological areas, ensure a continuous flow of funding for companies conducting research, improve the grant system and maintain innovative partnerships.

The effectiveness of government programs remains extremely low. The national innovation system in its development faces a number of serious problems that hinder its effectiveness. In this sense, it is impossible not to agree with academician A.A. Kaygorodtsev, which focuses on the most urgent of them:

- low level of competitiveness of domestic science in comparison with foreign scientific schools;

- a high degree of risk in research and development for the private sector and the lack of effective risk-sharing mechanisms of the government (partial cost recovery);

- the underdevelopment of services for technology transfer;

- weak intellectual property protection;

- insufficient number of domestic intellectual property objects patented abroad;

- insignificant volume of foreign direct investment in the manufacturing industry;

- lack of qualified technical personnel in the development of new products and technological processes.

The Solution of the tasks is a necessary condition for accelerating the development of the innovative sector of the national economy [4].

Annual expenditures on science in 2016-2019 in Kazakhstan remained quite low. For 2020 planned significant increase by $56.4 \%$. Information on types of financing is not yet publicly available. If we analyze the structure of the distribution of public expenses allocated for R \& D, in Kazakhstan, grants from state budget's trust funds are mainly directed to basic researches. 


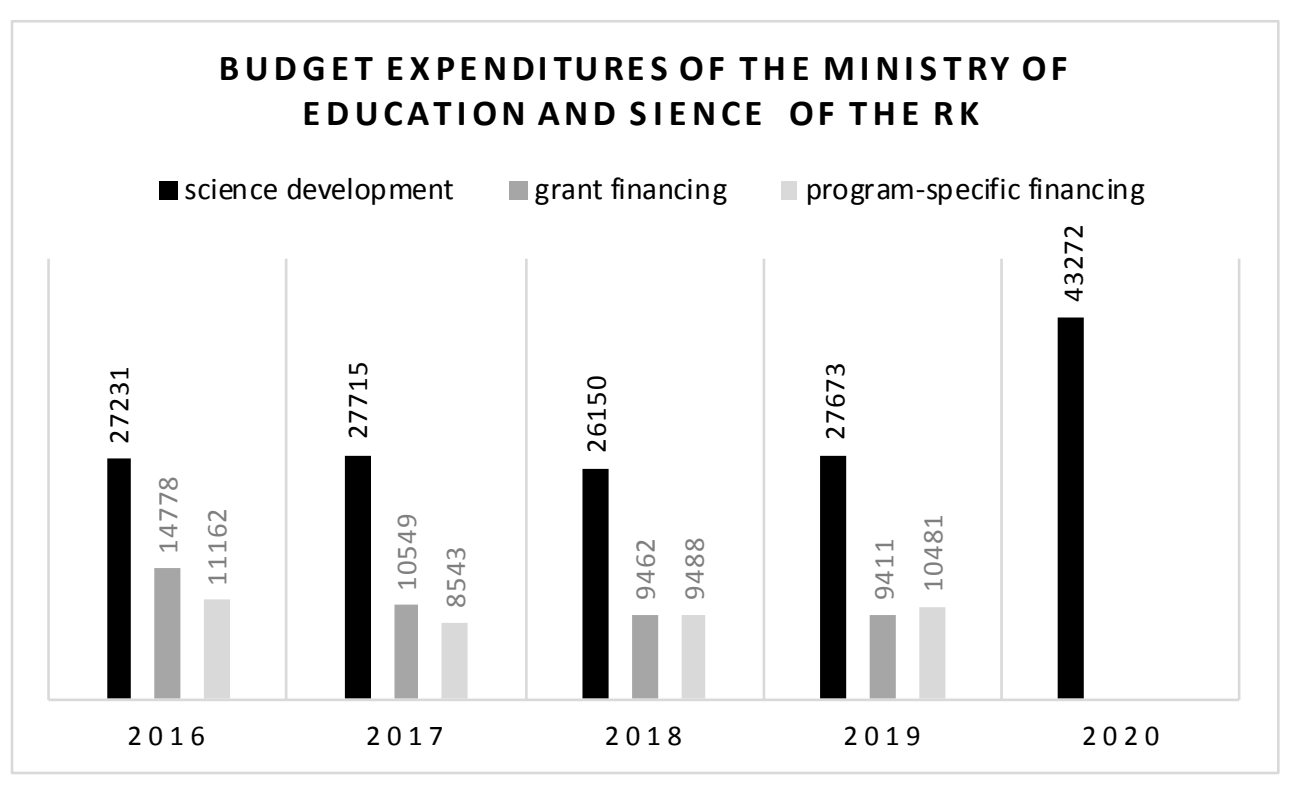

Figure 1 - Budget expenditures of the Ministry of education and science of the Republic of Kazakhstan, million tenge

Note - Source: Compiled on the base of [5].

As for scientific and technical developments, applications and services, budget allocations for their execution have almost ceased. The main source of small-scale financing of innovations in industrial enterprises is their own assets and the customer's funds. Lack of funds from potential customers caused a decrease in demand for development and scientific and technical services [6, p. 42].

By the end of 2019 the total amount of grants of the IT sector equal to $20.8 \%$.

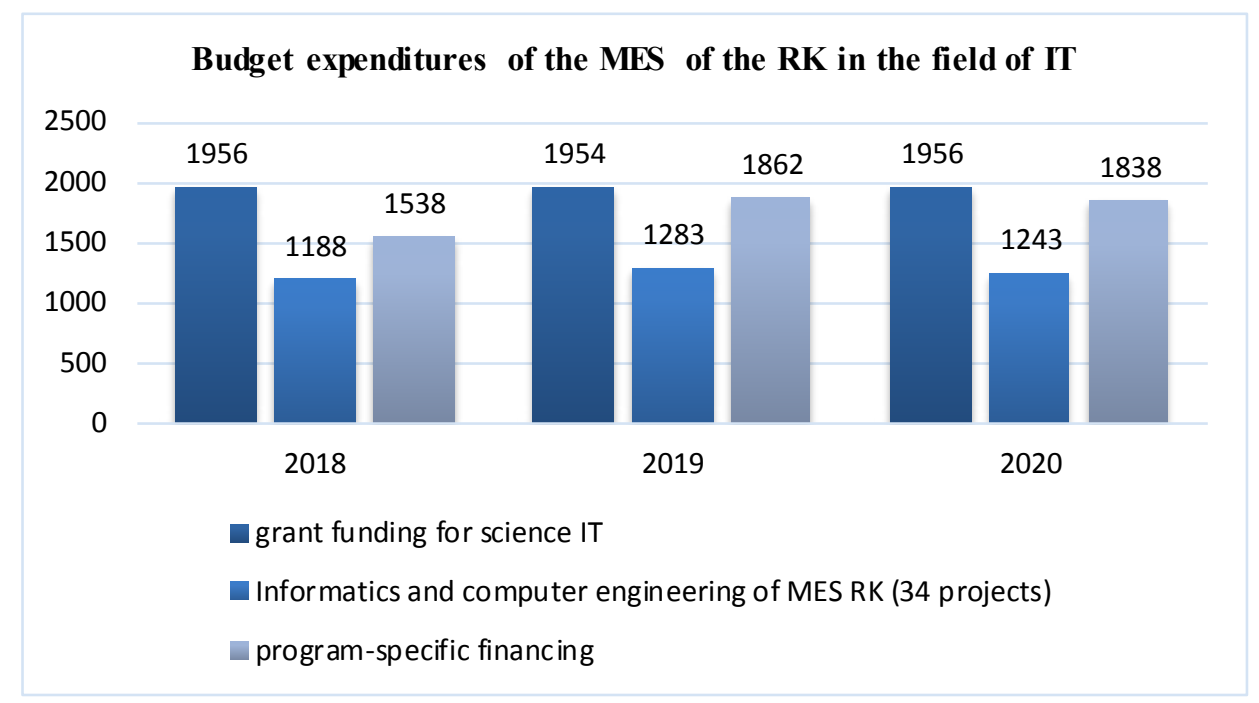

Figure 2 - Expenditures of the Ministry of education and science in the field of IT, million tenge

Note - Source: Compiled on the base of [5].

Before the state program "Digital Kazakhstan", the IT sector developed exclusively through private investment. Since the beginning of the program, grants from the state budget have been allocated for the development of the IT sector. Figure 3 shows information on grant funding and program-specific funding for science under the priority of the program: "Information, telecommunications and space technologies, scientific research in the field of natural Sciences". 
The expert opinion of representatives of the venture Fund "Qaz Tech Venture" will help us to complete the picture of the existing practice of supporting innovation and entrepreneurship in Kazakhstan. In order for public investment in the development of science, it is necessary to have an effect by increasing the level of commercialization of research results and by bringing them to practical fulfilment. In this sense, Singapore, which has one of the most well-developed technology start-up ecosystems in Southeast Asia, has a significant potential for sharing experience with Kazakhstan. We are talking about numerous common projects focused primarily on the exchange of experience and attracting overseas investment in Kazakhstan's technology projects. The example of such cooperation is a joint project of Singapore ("Quest Ventures Asia Fund II") and Kazakhstan ("Qaz Tech Venture"), launched in 2018. This is a venture fund that searches, for and selects startup projects for investing and improves the technological competence of project participants, by consulting and technological support, by stimulating the creation of commercially advantageous projects and companies. The fund created to promote the formation of technological entrepreneurship through venture financing, business incubation and technology consulting. QazTech Ventures is part of the Baiterek "National managing holding".

The venture fund "QazTech Ventures"improves the skills of the population in the field of venture financing and technology entrepreneurship, develops a business incubation system and stimulate the introduction of new technologies in corporations, develop the regulatory framework, and collaborate with leading international venture funds. The fund has achieved great results in these areas. The venture fund "QazTech Ventures"conducts a technological assessment of the project for laying fiberoptic communication lines. As a result of the successful completion of the project, it is planned to lay $20,751 \mathrm{~km}$ of fiber-optic cable, which will provide access to high-speed Internet for 828 rural localities across the Republic of Kazakhstan. The project is aimed at transforming traditional sectors of the economy, developing human capital, digitalizing the activities of government agencies, and developing digital infrastructure. As part of the development of the venture market, the Fund cooperates with the American venture Fund 500 Startups and the Singapore venture Fund "Quest Ventures Asia Fund II". In addition, a trilateral memorandum of cooperation was signed between "NMH "Baiterek", "QazTech Ventures" and the National innovation Agency of Thailand.

Funds created together with partners, finance start-up projects in Kazakhstan and Central Asia. In addition, successful startups get the opportunity to participate in acceleration programs, get knowledge from leading international experts, test the product in real conditions and attract investment, which, in turn, contributes to the development and scaling of the project, on the local market and abroad.

As part of its analytical activities, the foundation is actively implementing a long - term planning tool-foresight. In 2019, the Fund with the Asian development bank held the first foresight session "Development of long-term competitiveness of Kazakhstan". Partners of the session are also Narhoz University and the leading organization of the Russian Federation in this field "Theplatform for Scientific and Technical researches".

Development system of the business incubation provides financial and methodological support for private business incubators (co-financing of 50\% of operating expenses, but not more than 35 million tenge per year). In addition, incubation system provides state grants to residents of business incubators in the industrial-innovative projects to create new or significantly superior product or business process (up to 50 million tenge and not more than $80 \%$ of the reasonable costs). In 2019, methodological support was provided to the 3 business incubators: "BI Innovations" LLP (Nur-Sultan), "SmArt Point Almaty" LLP (Almaty), "Business incubator" MOST" LLP (Almaty).

The venture Fund organizes master classes, seminars, and forums in order to develop competencies in the field of venture financing, business incubation, and technology entrepreneurship. So, in 2019, within the framework of the Astana economic forum in Nur-Sultan, was held a session of venture financing. To the session invited foreign experts. The topic of the session was: "the Role of the state in development venture capital", and also "Industry 4.0".

Also in Nur-Sultan was held the forum "QTV SESSIONS", where experts discussed key issues of the growth in the venture financing market, long-term high-risk investments in the capital of new hightech startups, global technological trends, development of the business incubation system, introduction of corporate innovations, and others. In order to promote the expansion of private business incubators in the country's regions and further promote startups, the fund "Qaz Tech Ventures" held series of 
master classes where leading experts shared their practical experience on how to create an incubator, how to work with startups and what an investor is looking for in projects.

According to experts, today in Kazakhstan, much attention is paid to supporting innovation and entrepreneurship. The programs of the first and second 5-year have been implemented, and today the program of industrial. Innovative development programfor 2020-2025 has been adopted. In addition, the recommendations of the OECD and the Strategic plan of the Republic of Kazakhstan until 2025 are being realized.

The country's statistical indicators have improved as a result of the industrialization programs. Innovation activity since 2010 has grown from $4.0 \%$ to $10.6 \%$ in 2018 , and the share of innovative products in relation to GDP - from 0.65 to $1.91 \%$.

Representatives of the Fund noted that within the framework of the Unified business support and development program "Business Roadmap 2020", Qaztech Ventures fund has implemented a business incubation program. As a result of the total number of business incubators which accepted for incubation and supported was 71 projects. In 2019, business incubator projects attracted investments more than 230 million tenge. One of the successful examples of implemented projects is "Clockster". This project allows you to safely and carefully help manage the working time of employees, keeps records of vacations, business trips, time off and helps the business to be as effective as possible. The company attracted investments in the amount of more than 90 million tenge. The project also works in foreign markets.

To attract private risk financing and create start-up conditions for young innovative companies, the Astana International Smart Technologies Hub was created on the basis of the EXPO-2017 infrastructure. This is a unique platform for attracting venture investors, business angels, private equity funds and other investors on the one hand, and startup innovators from all over the world looking for funds to commercialize their ideas, on the other hand. As part of the Techno park of IT projects, the Accelerator 7.0 has been launched. For the effective interaction between all participants, support tools of the program have been identified created a technological infrastructure. It also provides interaction with the Science Park at the "Nazarbayev University", which will become a partner for start-upsinnovators in the development and in the testing ideas [7].

Kazakhstan also creates incentives to increase the interest of companies in developing innovative products, services and introducing new technologies. Enterprises at the legislative level are provided with conditions that provide for the prospects and advantages of their long-term investment in R \& d and innovation. In 2020, the tax legislation changed, exactly changed the definition of R \& d, simplified the mechanisms for deducting $\mathrm{R} \& \mathrm{~d}$ expenses from taxable income, revised the rules regarding deduction in the case of unsuccessful innovations, and the list of acceptable costs ( $\mathrm{R} \& \mathrm{~d}$ expenses of companies for which $\mathrm{R} \& \mathrm{~d}$ is not the main activity).

Today, due to the difficult situation related with the spread of the Covid-2019 virus, there is a positive trend in the use and implementation of digital technologies in all processes of human life: from the consumer goods and services sector, medicine, education, e-government to manufacturing, transport and logistics. The sudden problem gave the acceleration of technological modernization.

For real and full integration into the world technological community, it is necessary to increase the key indicators of scientific and technical development of the country. Kazakhstan relies on the positive experience of developing the innovation ecosystem not only European countries, but also successful experience of Asian innovation growth. Today concluded different international memoranda and agreements on scientific and tech cooperation.

The entrance of Kazakhstan into the world's leading technological countries will achieve the noticeable effects, if there are competitive domestic innovative products, enterprises, knowledge, technology, labor and the national innovation system.

\section{LIST OF LITERATURE}

1 Official website of RSBS "Business in Singapore". [Electronic source]. - URL: https://www.rsbu.org/ biznes-v-singapure (date accessed: 19.03.2019).

2 Kovalev M.M. (2017). China in the XXI century - a global innovative power / M.M. Kovalev. - Minsk: Publishing House. BSU Center, 2017. 239 p. 
3 The Action Community for Entrepreneurship (ACE) Singapore. [Electronic source]. - URL: www.ace. org.sg. (date accessed: 01.10.2018).

4 Kaygorodtsev A.A. (2016). Problems of innovative development of Kazakhstan. [Electronic source]. URL: http://www.rusnauka.com/17_ENXXI_2016/Economics/16_213226.doc.htm (date accessed: 08.12.18).

5 National scientific portal of the Republic of Kazakhstan. The President's decree of approval the strategic development plan of the Republic of Kazakhstan until 2025, dated 15/02/2018. [Electronic resource]. - URL: http://nauka.kz (date accessed: 20.02.2018).

6 Baimbetova A.A. (2010). Innovation as a direction of the state development strategy of the Republic of Kazakhstan // Bulletin of KazNU. Economic Series, 2010. No. 4. P. 40-44.

7 Astana International Smart Technologies Hub. [Electronic source]. - URL: https://astanahub.com/ (date accessed: 01.10.2018).

Г.У. ХАДЖИЕВА, ${ }^{1}$

э.Ғ.К., профессор.

А.Е. НУРАЛІМ, ${ }^{1}$

магистр.

«Тұран» университеті ${ }^{1}$

\title{
ҚЫТАЙ, СИНГАПУР ЖӘНЕ ҚАЗАҚСТАН: ХАЛЫҚАРАЛЫҚ ТЕХНОЛОГИЯЛЫҚ ЫНТЫМАҚТАСТЫҚ ТӘЖІРИБЕСІ
}

\begin{abstract}
Андатпа
Қазіргі жағдайда әдеттегі халықаралық сауда шеңберіне сүйене отырып, өнеркәсіптік өндіріс, халықаралық инвестициялық өзара іс-қимыл, бірлескен ғылыми-техникалық қызмет саласында тікелей кооперациялық байланыс болып табылатын мемлекетаралық өнеркәсіптік ынтымақтастықтың рөлі артады. Халықаралық технологиялық алмасу ғылыми-техникалық прогрестің жетістіктерін тарату функциясын орындай отырып, әзірлеуден бастап коммерциялық қолдануға дейінгі жұмыстардың барлық циклінің тиімділігіне әсер етеді. Технологиялармен алмасу нысандары берілетін технологияның сипаттамаларымен және беру процесі субъектілерінің ерекшеліктерімен негізделеді. Технология немесе технологиялық сыйымды өнім алушы серіктестің ғылыми-технологиялық тәжірибесінің басым бөлігін ассимиляциялау мүмкіндігіне ие болады. Мақалада Сингапур мен Қытай сияқты Азия елдерінің технологиялық дамуының жекелеген аспектілері, зияткерлік меншікті құқықтық қорғау және әлемдік технологиялық процестерге белсенді кіруге ұмтылатын Қазақстан мен басқа да елдер үшін қызықты халықаралық технологиялық алмасу саласындағы тәжірибе қарастырылады. Қазақстанда инновацияларды қолдаудың, жоғары технологиялық салаларды ынталандырудың қолданыстағы жүйесіне баға беріледі. Шетелдік сарапшы, the Action Community for Entrepreneurship Сингапур ұйымының директорының орынбасары Брайн Патрик Тан, сондай-ақ «Qaz Tech Venture» венчурлік қоры өкілдерінің Қазақстанның халықаралық ғылыми-техникалық кеңістікке кіріуінің әлеуеті туралы сараптамалық пікірі келтіріледі.
\end{abstract}

Тірек сөздер: технологиялық алмасу, лицензиялау, ғылыми-техникалық кооперациялау, зияткерлік меншік, әлеует, кіру, жоғары технологиялық салалар.

Г.У. ХАДЖИЕВА, ${ }^{1}$ к.э.Н., профессор. А.Е. НУРАЛИМ, ${ }^{1}$ магистр.

Университет «Туран» ${ }^{1}$

\section{КИТАЙ, СИНГАПУР И КАЗАХСТАН: ОПЫТ МЕЖДУНАРОДНОГО ТЕХНОЛОГИЧЕСКОГО СОТРУДНИЧЕСТВА}

\begin{abstract}
Аннотация
В современных условиях возрастает роль межгосударственного промышленного сотрудничества, которое, выходя за рамки обычной международной торговли, представляет прямую кооперационную связь в области промышленного производства, международного инвестиционного взаимодействия, совместной научнотехнической деятельности. Международный технологический обмен, выполняя функцию распространения
\end{abstract}


достижений научно-технического прогресса, влияет на эффективность всего цикла работ, от разработки до коммерческого применения. Формы обмена технологиями обусловливаются характеристиками передаваемой технологии и особенностями субъектов процесса передачи. Получатель технологии либо технологически емкой продукции приобретает возможность ассимилировать большую часть научно-технологического опыта партнера. В статье рассматриваются отдельные аспекты технологического развития таких азиатских стран, как Сингапур и Китай, опыт которых в области правовой защиты интеллектуальной собственности и успешного международного технологического обмена представляет интерес для Казахстана и других стран, стремящихся к активному интегрированию в мировые технологические процессы. Дается оценка существующей системы поддержки инноваций, стимулирования высокотехнологичных отраслей в Казахстане. Приводится мнение зарубежного эксперта, заместителя директора сингапурской организации The Action Community for Entrepreneurship Брайна Патрика Тана, а также представителей венчурного фонда AO «Qaz Tech Venture» o потенциале интегрирования Казахстана в международное научно-техническое пространство.

Ключевые слова: технологический обмен, лицензирование, научно-техническое кооперирование, интеллектуальная собственность, потенциал, интегрирование, высокотехнологичные отрасли. 